\title{
Implementation of Child Friendly Schools Based on Character Education Habits of Reading Asmaul Husna and Courtesy of Elementary School Students
}

\author{
Muhamad Afandi ${ }^{1}$, Yulina Ismiyanti ${ }^{2}$, Sri Wahyuningsih ${ }^{3}$ \\ Universitas Islam Sulatan Agung, Semarang, Indonesia ${ }^{1,2}$ \\ Institut Agama Islam Negeri Kudus ${ }^{3}$ \\ \{mafandi@unissula.ac.id¹ ,yulinaismiyanti@unissula.ac.id², wahyuningsih@iainkudus.ac.id ${ }^{3}$ \}
}

\begin{abstract}
The research aims to describe the implementation of child-friendly schools based on the character education of Asmaul Husna's reading habits and elementary school students' politeness. This research is a research with a qualitative descriptive approach. The research used interview, observation and document analysis methods for data collection. The subjects of this study were the principal, teachers and students. The data validity technique used was content validity and triangulation. The analysis technique uses the stages of data reduction, data presentation and drawing conclusions. The results showed that the implementation of character education-based child-friendly schools in Srondol Wetan 2 Elementary School was in accordance with the child-friendly school policy which eliminates violence in the school environment, the applied curriculum promotes the implementation of fun learning in schools. The fulfillment of educators and education personnel who are trained in child rights, which are complete, starting from the principal to the parents or guardians of students who work together with the school. The facilities and infrastructure are complete to support the implementation of child-friendly schools. Children's participation in implementing child-friendly schools is realized by the presence of picket children as a form of student participation. Parents' participation in implementing child-friendly schools can be seen from the parent association and parent association meetings which are held regularly every month. The character education that students have in reading Asmaul Husna can be seen that some students have memorized Asmaul Husna and are excited, enthusiastic and happy to follow the habit of reading Asmaul Husna as an encouragement so that students know the names of Allah SWT and are able to imitate Him so that good morals are formed from each. students. Meanwhile, the character of student politeness is the result of implementing child-friendly schools due to the coaching carried out by the school for its students. Coaching is carried out by both the principal and the teacher. Coaching is carried out at morning apples and in the classroom before the start of learning.
\end{abstract}

Keywords: Child Friendly Schools, Character Education, Asmaul Husna Reading Habits, Student Modesty 


\section{Introduction}

Education is a basic right of children that must be fulfilled, so the fulfillment of children's rights in schools needs coordination and cooperation from various stakeholders. These parties include the government, educators and education staff, parents and guardians of students, school committees and the community. The fulfillment of children's rights in schools is not only providing services for teaching and learning activities and providing facilities, but also services that must be based on the fulfillment of children's rights based on the principles of non-discrimination, the best interests of the child, the right to life, the child's survival, and their development. . In addition, respect for children's opinions must also appreciate children for having the courage to express their opinions. If all stakeholders can coordinate and cooperate well and are based on the principles of children's rights, the fulfillment of children's rights and protection in schools will be realized.

The educational environment, such as schools, must be a safe place for children. A safe school environment can be seen by the presence or absence of discriminatory acts and violence that can violate children's rights. Therefore, acts of violence between students and between students and teachers must be kept away from schools to create a safe and comfortable educational environment. Because children need protection wherever they are, even in the school environment.

To realize the fulfillment of child protection rights against discrimination and suppress acts of violence in the world of education, especially in the school environment, the government has launched "Child Friendly Education." With the launch of child-friendly education, childfriendly schools can be realized from the government for its concern about the protection of children in the school environment. Protection of children are activities that guarantee and protect children and their rights so that they can grow and develop and participate optimally in accordance with their dignity and get protection from discrimination.

Child Friendly is a policy initiated and pursued by educational institutions in Indonesia as an effort to take preventive measures in overcoming various problems that violate children's rights in the educational environment. Several variables include school buildings, environmental settings, teaching and learning processes, resources and materials, teachers, school principals, health and safety.

Child-friendly schools [1] are a concept initiated and attempted to be actualized by the UNICEF study. Child Friendly Schools have several variables including school buildings, environmental settings, teaching and learning processes, resources and materials, teachers, school principals, health and security. In an era like now, technological advances also greatly affect student behavior, because all the information desired can be easily accessed from the internet media, without any filtering first, it needs more attention and supervision from parents when a child uses internet media to search information required [2].

Elementary school is a place to plant character education, education that is instilled to shape the values of a person's character to be better and more dignified in society. Basically education is an effort made to change a condition or someone's behavior from not good to better, from immature to more mature according to the level of development [3].

Character education is defined as [4] as education that develops character values in students so that they have values and character as their own character, apply these values in their own lives, as members of society and citizens who are religious, nationalist. productive, and creative. Habituation activities in programmed learning Habitual activities in programmed learning can be carried out with special planning within a certain time, to develop individual, group and / or classical students' personalities. The moral aspect of knowing is implanted 
through classroom learning, while moral feeling and moral action are instilled both inside and outside the classroom. Of the three components, the moral aspect of action must be carried out continuously through habituation every day. [5]

The habit of reading Asmaul Husna every morning before learning begins with the aim of realizing student character. Asmaul Husna is the 99 names of Allah SWT, where each name is a description of the attributes of Allah. In Surat Thahaa verse 8:

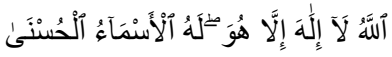

This means: He is God, there is no God (who has the right to be worshiped) but Him. He has Al Asmaul Husna or good names"

Asmaul Husna can be interpreted as the beautiful and best names of Allah which $\mathrm{He}$ mentioned himself and conveyed to the prophet Muhammad SAW. Disifati as a good and best name because Asmaul Husna shows that this name In learning interactions, apart from the habit of memorizing Asmaul Husna, there is also the character education of manners [6] an educational process that aims to make the individual person in a much better direction, namely by educating the character which later can be reflected in ethics, actions real namely noble behavior. Courtesy is the behavior of a person to always obey the social rules that exist in a society which is the impact of social interaction.

Regarding the implementation of child-friendly schools based on Asmaul Husna's reading habit and student politeness, it is based on the observation that the Srondol Wetan 02 Public Elementary School is one of the public schools in Banyumanik District designated to implement child-friendly-based schools and also implement character education. Basically, Child Friendly Schools have four principles, each of which contains policies, curriculum, school management and regulations, facilities, infrastructure and the environment as well as interpersonal communication / daily relationships between stakeholders and students, and among students. the implementation of Child Friendly Schools, namely that every morning there is a culture of 5S (Smile, Greetings, Greetings, Polite, Polite). Every morning the students shake hands with the teacher, then continue with the morning roll call and habituation of strengthening character education, strengthening the character education in question, namely politeness and reading Asmaul Husna. Asmaul Husna reading activity led by representatives of grade 5 and 6 children from the teacher's office using loudspeakers and followed by all students in grades 1-6 in their respective classes. This activity is carried out after the morning apple and the flag ceremony on Monday. This activity is what makes students have character. At the time of habituation there were still some students who could not follow the habituation activities, there were still many students who did not follow the solemn, have not memorized Asmaul Husna, played with friends and there were even some students who did not follow habituation because they were late coming to school. Students who are late will be subject to separate sanctions by the teachers who are in charge of security and discipline. After character strengthening, the next activity is teaching and learning activities, during teaching and learning activities the teacher applies two-way communication to students, so whatever the child's opinion can be accepted by the teacher and appreciated by the teacher, students are free to express their ideas and ideas.

In writing this article, we will describe the application of child-friendly schools based on character education with reading habits of Asmaul Husna and politeness at Srondol Wetan Public Elementary School 02. 


\section{Method}

This research approach uses a qualitative descriptive method. The research was conducted at the Srondol Wetan 02 Elementary School, Banyumanik District, Semarang City. The data source in the research using primary data was carried out by directly examining the Srondol Wetan 02 Elementary School. Data were obtained through interviews, observation and documentation. Secondary data comes from the field, the use of journals and from books that have a relationship with the issue to be discussed. Data collection techniques used observation sheets, interviews, questionnaires and documentation analysis. Data analysis techniques, Data Reduction: In qualitative data reduction research conducted by researchers, namely collecting data through interviews with principals, teachers and students, Data Presentation: presenting the data that has been obtained in the form of narratives and descriptions, Conclusion Drawing: drawing conclusions in order to answer the formula problem. Researchers check the data that has been obtained in the field with the aim of research. The data validity test is used by the researcher to test the validity of the credibility data, which when collecting data the researcher does so by using the triangulation of techniques and source triangulation processes. Technique triangulation in the research that the researcher did was by collecting data obtained from interviews, observation and documentation on the primary data sources of the study. While source triangulation was carried out by researchers by asking the same thing through data sources obtained from school principals, teachers and students.

\section{Result and Discussion}

\subsection{Implementation of Child Friendly Schools based on Character Education}

\section{a) Policy on Child Friendly}

Schools Child Friendly Schools are one of the policies implemented by Indonesian educational institutions as an effort to take precautions to overcome various problems that violate children's rights, especially when children are in school. This action is expected to provide awareness to teachers and students to eliminate acts of violence and discriminatory acts [7].

The Policy for Child Friendly Schools at Srondol Wetan 02 Public Elementary School is based on the Principal's Decree which states that the enactment of the Srondol Wetan 02 Public Elementary School as a Child Friendly School is found at number 421.2 / 134 / SK02 / IV / 2019 concerning the Formation of Child Friendly School Teams in Elementary Schools Srondol Wetan 02 of 2019. The principal considers that in the first point to improve the implementation of safe, comfortable, and fun learning in schools, schools need to take precautions and overcome violence in schools. On the second point, the principal considers that to implement point one school needs to carry out child-friendly learning by making the school child-friendly. Whereas in the third point the principal considers that in order for the implementation of violence prevention in schools to run smoothly, a child-friendly school team is formed. In the Principal's Decree, the researcher found that there were a series of laws, government regulations, presidential regulations, presidential instructions. Regulation of the Minister of National Education and Government Regulations. To support the implementation of child-friendly schools. So that four things were decided, first the educators and education staff whose names were listed in the decree served as the Child Friendly School Team. The 
two Child Friendly School Teams in the school environment as listed in the attachment to the SK. the three matters that have not been regulated in the Decree shall be regulated later, if there are deficiencies, they will be corrected. The four decisions take effect from the date that has been determined on April 10, 2019.

The composition of the Child Friendly School Implementation Team at the Srondol Wetan 02 Public Elementary School consists of a supervisor, a person in charge, the head of the implementation, a secretary and a treasurer. In the composition of the Implementing Team there are also teams that are divided into certain fields. The field of supervising the implementation of the child-friendly curriculum consists of five people, one of whom is the head of the field. The health and environmental surveillance sector consists of four people, one of which is the head of the field. The coordination and outreach division consists of four people, one of which is the chairperson. The monitoring and evaluation team consists of three people, one of which is the team leader. Then there is also the equipment series where both of them have the same position.

The 2019 School Principal Decree explains the duties and functions of the Child Friendly School implementation team. The first task of the implementing team in general is to coordinate efforts to develop Child Friendly Schools, to socialize the importance of childfriendly schools, to monitor the development of child-friendly schools and to evaluate. The second contains the duties of each field which consists of the supervisor, the person in charge, the chief executive, the supervision of the implementation of the child-friendly curriculum, the coordination and socialization sector and the monitoring and evaluation sector. The supervisor is in charge of assisting and facilitating the formation and development of child-friendly schools. The person in charge is in charge of ensuring that programs run properly according to regulations. The chief executive ensures and controls the implementation of child-friendly schools from formation to implementation. The area of supervising the implementation of the child-friendly curriculum ensures and supervises the use of positive discipline during teaching and learning activities. The field of coordination and outreach is in charge of coordinating the program with related parties and ensuring student involvement in the formation and development of child-friendly schools. The monitoring and evaluation sector is in charge of monitoring program implementation from its inception to its implementation, monitoring members also involve students.

Meanwhile, for the pamphlet photo, the researcher took a photo of the pamphlet stuck in front of the teacher and principal's office. There are two pamphlets posted in front of the office, the first pamphlet contains contact complaints in case of bullying or bullying in the school environment. The pamphlet also contains the telephone number of the Semarang City education office, the Banyumanik Police telephone number, the Semarang Polrestabes phone number and the Semarang City Education Office phone number and the school phone number. Meanwhile, the second pamphlet contains the principal's personal telephone number. Pamphlets are posted in front of the teacher's office so that all school members can see them. So that if there is bullying or bullying at school, the school can immediately follow up.

The contents of the first pamphlet regarding child-friendly schools are based on the researcher's description, namely the pamphlet in front of the teacher's office which contains the words "Let's Create a Safe and Comfortable School for Children, When Experiencing Bullying, Persecution, Bullying and the Like ..." and accompanied by a telephone number Related parties include the Ministry of Education and Culture, Semarang Police, Banyumanik Police, Semarang City Education Office and Schools. Meanwhile, the second pamphlet contains the sentence "In the event of Bullying of Persecution and Bullying in School" in which there is a complaint contact in the form of the principal's personal number. The contents 
of the pamphlet indicate that the school is really serious in following up if there is bullying, persecution, bullying or other similar things that violate the provisions of child-friendly schools.

\section{b) Implementation of the Curriculum}

The curriculum of Srondol Wetan 02 Public Elementary School has a child-friendly Learning Implementation Plan. The arrangement of the classroom environment is also made in a comfortable way to support learning. Schools provide learning that develops students' potential, interest, talents and creativity. Schools carry out learning in a fun way that is free of discrimination. The school also has indoor and outdoor rooms to support students in learning. Teaching teachers apply various forms of assessment. The assessment is on the aspects of learning, including attitudes, knowledge and skills of students.

\section{c) Educators and Education Personnel Trained in Children's Rights}

In schools where there is a principal in charge. Schools also have teachers whose number corresponds to the number of students attending school, but when interviewing teachers and principals they said that the school did not have a librarian. At school there are administrative staff, school janitors, school committee members, extracurricular advisers and parents or guardians of students who work with the school.

\section{d) Facilities and Infrastructure for Child Friendly Schools}

Schools have classrooms according to the number of students. The school also has childfriendly learning tools. The school has an adequate number of toilets. The sewers in the school are well made so they don't pollute the environment. Besides that, the school has a place to wash hands. Schools also equip it with clean water. Schools have safe gathering points. Routes and places for evacuation are recognized by all school residents. The school has rooms that support the implementation of child-friendly schools including the Student Health Unit, creativity room, sports room, play area, library room and healthy canteen. In order to support the health of students, schools provide garbage dumps in each class. As a school that implements a child-friendly school, Srondol Wetan 02 Public Elementary School has a symbol or sign related to child-friendly schools. As a full provision of children's rights, schools must provide adequate facilities and infrastructure.

\section{e) Child participation}

The implementation of child-friendly schools must involve students to participate. that this child-friendly school program prioritizes participatory activities for students [8]. Schools involve students in forming or compiling school policies and regulations. Schools empower students who excel to become picket children. The picket child was invited to discuss the formulation of school policies and rules. The school empowers students as cadres of health, preparedness, safety and comfort of the school, so a little doctor and a Youth Red Cross are formed. 


\section{f) Participation of Parents / Guardians of Students}

Parents or guardians of students participate in realizing child-friendly schools by providing time to respond to children's ventures, ensure the growth and development of children's interests and talents, supervise children's security, safety and comfort, attend coordination meetings for child-friendly schools, participate in facilitating activities related to child-friendly schools and participate in building facilities and infrastructure to support friendly schools child.

\subsection{Character Education Asmaul Husna Reading Habits and Politeness}

Humans have different characters that are unique psychologically in the form of friendly, disciplined, honest, caring, and responsible. In education, a teacher's duty is not only to teach but also to foster student character so that good personality or character is achieved. Among these good characters are religious, disciplined and caring for the environment as stated in the vision and mission of the Srondol Wetan 02 Elementary School. Character education in developing and fostering student character. This is very important because sometimes the character education provided in the family environment is still lacking due to the lack of attention of parents towards their children.

Character is behavior and not knowledge so that to be internalized by students, a model or exemplary must be given in addition to being taught in a way that suits the conditions of students [9]. Character education in schools can be done in various ways including: (a) Integrating character education into all subjects. (b) Integrating character education in daily activities in schools, (c) Integrating character education into programmed and planned activities. (d) Build communication and cooperation between schools and parents of students. As for the habituation of reading Asmaul Husna's character and the politeness of students as follows:

\subsubsection{Reading Habits Asmaul Husna}

Asmaa-ul Husnaa [10] are the names of Allah who are ordered to be read in prayer. In accordance with His words in Surah Al-Arof verse 180 meaning that It only belongs to Allah Asmaa-ul Husna, so ask Him by chanting Asma-Ul Husna and leave those who deviate from the truth in (mentioning) His names. Later they will get a reply for what they have done.

Asmaul Husna customization is a method used by schools in integrating character education into daily activities at school that have been planned by the school. Asmaul Husna's reading habit is a realization of the school's vision, which is to make students excel in science and technology and realize faith and piety and realize one of the school goals, namely students are able to follow developments in science and technology and get used to carrying out religious orders. The following is to carry out the habit of reading Asmaul Husna, it is necessary:

\section{a) Frequency and continuity of Asmaul Husna Reading Habitual Activities}

In an activity there must be a routine or how often done in order to be able to succeed an activity. Frequency or continuity itself means continuity, continuity and continuity or it can be said how routine it is done. At Srondol Wetan 02 Public Elementary School, there is an activity program, namely Asmaul Husna's reading habit. This activity aims to foster good 
religious attitudes and form good morals and personalities. This activity is usually carried out after the morning apple every Tuesday and Thursday. So, in one week do these activities for 2 times and these activities are routine school activities and have been scheduled. The process of these activities took place at 07.15 and finished at 07.30 ( 15 minutes) before the lesson began. These activities are carried out by all school members, especially students. In the habit of reading Asmaul Husna, it is led by student representatives who have been appointed by the teacher, usually taken in the upper-level classes, namely grades 4,5 and 6 because they are considered capable of doing it for designated student representatives then go to the teacher's room to read them through loudspeakers so that they can be heard in their respective classrooms. For the students in the class, prepare a sheet containing Asmaul Husna so that students can read it together. Non-Muslim students stay in the class and pray according to their respective beliefs. On the other hand, the teacher or homeroom teacher guides and accompanies students to remain solemn in reading them. The role of Asmaul Husna's reading activity is as a medium for prayer for students before learning science. Based on the results of the research, the Asmaul Husna reading activity is carried out routinely on Tuesday and Thursday after the morning apple and takes place at $07.15-07.30$ or 15 minutes before the lesson starts.

\section{b) Asmaul Husna Reading Habit Implementation Place}

Srondol Wetan 02 State Elementary School has a program of activities that are carried out routinely every day, namely the habit of reading Asmaul Husna. Of course, these activities have been carried out in every school, especially at Srondol Wetan 02 Elementary School. In the process, these activities take place solemnly and regularly. This is supported by comfortable classrooms. This habituation takes place in their respective classrooms and there are student representatives taken at the top level such as grades 4, 5 and 6 who are considered capable of doing so. In each classroom, there are speakers in order to hear the voice leading from the teacher's room with loudspeakers.Based on the results of the research that the place of implementation for Asmaul Husna's reading habits is in each classroom with the guidance of the teacher or homeroom teacher for each class.

\section{c) When the Asmaul Husna Reading Habit was Implemented}

Asmaul Husna's reading habit activities at Srondol Wetan 02 State Elementary School are carried out routinely and on a scheduled basis. For the implementation schedule of reading Asmaul Husna on Tuesday and Thursday or 2 times a week. This activity was attended by all members of the school who are Muslim. This is expected to foster students' religious character in good things. It is also hoped that schools will remain consistent in implementing these activities. The reading activity of Asmaul Husna takes place after the morning roll call at 07.15-07.30 or 15 minutes before the lesson starts. In this case, students will be accustomed to good things and can condition students before learning begins. Based on the results of the research, the Asmaul Husna reading activity is carried out every Tuesday and Thursday after the morning apple and takes place at $07.15-07.30$ with a duration of 15 minutes.

\section{d) The Process of Implementing Asmaul Husna's Reading Habits}

Asmaul Husna is a series of beautiful names of Allah SWT, saving grace that shows the perfection of Allah SWT. Based on the results of interviews and observations, it shows that 
the process of implementing character education at Srondol Wetan 02 Elementary School is followed by all school members. Class teachers or other teachers can accompany the class when activities take place, so that class conditions are more effective and students can follow Asmaul Husna's reading habits solemnly. When habituation will take place students have been distributed sheets containing Asmaul Husna with the aim that students can read it. Based on the results of the research that the activity process was going well and regularly. In each class, a sheet containing Asmaul Husna has been distributed with the aim that students can read it every time the habituation takes place. The habituation process is usually accompanied by a class teacher or homeroom teacher respectively.

\subsubsection{Habits of Student Courtesy}

Based on the results of the research that at the Srondol Wetan 02 Public Elementary School, since the implementation of child-friendly schools, students have become accustomed to greeting school residents and guests who come to school and are accustomed to greeting school residents and residents. guests who come to school. Students will immediately apologize if they have made a mistake, they apologize using good sentences and intonations. When asking students to help use good sentences and intonation. Students are also used to saying thank you with good sentences when they have been helped. Students say thank you with a good intonation when it has been helped. Students use greeting words that are good for other students and school members. In addition, students communicate with other students and other school members with good sentences and intonations. Student politeness increases due to coaching in schools. Coaching that is carried out repeatedly and continuously makes school residents increase their level of awareness of politeness. So if someone behaves inappropriately, they will be directly reprimanded and given guidance. Politeness [11] social rules that lead to matters relating to the way a person behaves naturally in social life and the friendly attitude shown to several people in front of him with the intention of respecting and respecting that person, to create comfortable and harmonious conditions, politeness is an obligation that must be done by every group, from children to the elderly without any exception.

\section{Conclusion}

The implementation of child-friendly schools in Srondol Wetan 02 Elementary School is in accordance with the indicators of child-friendly schools that have been determined. These indicators include child-friendly school policies which eliminate violence in the school environment. Implementation of a curriculum that emphasizes the implementation of fun learning in schools. The fulfillment of educators and education personnel who are trained in child rights, which are complete, starting from the principal to the parents or guardians of students who work together with the school. The facilities and infrastructure at Srondol Wetan 02 Public Elementary School are also complete to support the implementation of a childfriendly school. Children's participation in implementing child-friendly schools is realized by the presence of picket children as a form of student participation. Parents' participation in implementing child-friendly schools can be seen from the parent association and parent association meetings which are held regularly every month.

Character education in schools is carried out in various ways including: (a) Integrating character education into all subjects. (b) Integrating character education in daily activities in 
schools, (c) Integrating character education into programmed and planned activities. (d) Build communication and cooperation between the school and the parents of students. The characters that are manifested are the habit of reading Asmaul Husna and the politeness of students.

\section{References}

[1] F. Çobanoğlu, Z. Ayvaz-Tuncel, and A. Ordu, "Child-friendly schools: An assessment of secondary schools," Univers. J. Educ. Res., vol. 6, no. 3, pp. 466-477, 2018, doi: 10.13189/ujer.2018.060313.

[2] F. Fahrudin, "Penanaman Karakter Sopan Santun di SDN Ngabeyan 03 Kartasura Tahun Tjaran 2017/2018," Univerwsitas Muhammadiyah Surakarta, 2018.

[3] Munjiatun, "Penguatan Pendidikan Karakter," J. kependidikan, vol. 6, no. 2, pp. 334349, 2018, doi: https://doi.org/10.24090/jk.v6i2.

[4] Zubaedi, Desain Pendidikan Karakter 'Konsepsi dan Alokasinya dalam Lembaga Pendidikan". Jakarta: Prenada Media, 2015.

[5] B. Maunah, "Implementasi Pendidikan Karakter Dalam Pembentukan Kepribadian Holistik Siswa," J. Pendidik. Karakter, vol. 1, pp. 90-101, 2015.

[6] F. R. Putra, A. Imron, and D. D. N. Benty, "Implementasi Pendidikan Karakter Sopan Santun Melalui Pembelajaran Akidah Akhlak," JAMP J. Adminitrasi dan Manaj. Pendidik., vol. 3, no. 3, pp. 182-191, 2020.

[7] Sri Lestari, "Implementasi Sekolah Ramah Anak di SD Negeri Ngupasan Yogyakarta," Universitas Islam Negeri Sunan Kalijaga, 2017.

[8] R. D. Utami, M. K. D. Saputri, and F. N. Kartikasari, "Implementasi Penerapan Sekolah Ramah Anak Pada Penyelenggaraan Pendidikan Sekolah Dasar," in The 5th URECOL Proceeding, 2017, no. February, pp. 170-176.

[9] A. Sari, "Implementasi Pendidikan Karakter Di Sekolah Melalui Kegiatan Pembiasaan Dan Keteladanan,” Tarbawi J. Keilmuan Manaj. Pendidik., vol. 3, no. 02, pp. 249-258, 2017.

[10] A. Al-Hafidh, Keistimewaan dan Peranan Al Asmaul Husna di Zaman Modern. Semarang: Aneka Ilmu, 2014.

[11] K. Diriaika, "Peranan Guru Pendidikan Kewarganegaraan Dalam Meningkatkan Kesopanan Peserta Didik (Studi Deskriptif pada Peserta Didik Kelas XI SMA Kemala Bhayangkari Bandung," Universitas Pasundan, 2017. 